\title{
Effect of Planting Density and Fertilizer Rate on Some Physiological Parameters of Arabica Coffee Seedlings
}

\author{
Wubishet Tamirat ${ }^{1, ~ *}$, Amsalu Gobena ${ }^{2}$, Taye Kufa ${ }^{3}$ \\ ${ }^{1}$ Ethiopian Institute of Agricultural Research, Jimma Agricultural Research Center, Jimma, Ethiopia \\ ${ }^{2}$ College of Agriculture, School of Plant and Horticultural Sciences, Hawassa University, Hawassa, Ethiopia \\ ${ }^{3}$ International Institute of Tropical Agriculture, Burundi-Station, Bujumbura, Burundi
}

\author{
Email address: \\ wubishettamirat3@gmail.com (W. Tamirat) \\ ${ }^{*}$ Corresponding author
}

\section{To cite this article:}

Wubishet Tamirat, Amsalu Gobena, Taye Kufa. Effect of Planting Density and Fertilizer Rate on Some Physiological Parameters of Arabica Coffee Seedlings. International Journal of Science, Technology and Society. Vol. 9, No. 5, 2021, pp. 222-227.

doi: $10.11648 /$ j.ijsts.20210905.13

Received: August 31, 2021; Accepted: October 12, 2021; Published: October 28, 2021

\begin{abstract}
Planting high density can reduce photosynthetic active radiation due to mutual shading or low light interception. The nature of the canopy and utilization of solar radiation influence the performances of coffee genotype. This study was designed to evaluate the effect of planting density and fertilizer rate on physiological parameters of Arabica coffee seedlings under nursery conditions. It was conducted at the Jimma Agricultural Research Center in southwest Ethiopia in 2018 season. A factorial experimentation in a completely randomized design with three replications was used for the study. The treatments consisted of combinations of two Arabica coffee cultivars (compact-74110 and open-75227), four population densities per polythene tube (one, two, three and four) and three compound NPK fertilizer $(22: 6: 12+\mathrm{Te})$ rates (control, $5 \mathrm{~g}$ and $10 \mathrm{~g})$. The most common plant physiological parameters including NAR, AGR, RGR and CGR were estimated and analyzed using standard procedures. The results showed that interaction between cultivar, population density and fertilizer significantly ( $\mathrm{P}$ $\leq 0.05)$ influenced NAR and CGR, and highly significantly $(\mathrm{P} \leq 0.01)$ influenced AGR and RGR. The highest values of NAR, AGR, RGR and CGR were recorded from the lowest population density (PD1) and increased in the order of PD1 > PD2 > PD3 > PD4 for each parameter. Application of 5g of NPK significantly enhanced NAR, AGR, RGR and CGR as compared with other fertilizer rates, while these parameters were observed to decrease for $10 \mathrm{~g}$ of NPK perhaps due to toxicity problem. In general, high planting density decrease physiological parameters of the coffee plant, so more attention like intensive coffee tree management practices as well as optimization of population density should be done under field conditions to increase physiological parameters of the coffee plant.
\end{abstract}

Keywords: Coffee Nursery, Physiological Parameters, Compound Fertilizer, Population Density

\section{Introduction}

Light is the energy source for photosynthesis and an essential prerequisite for plant life. The process of photosynthesis could be inhibited, due to the presence of too little or too much light which creates a stressful environment for the system. Plant photosynthesis, hence, net assimilation rate is affected by different factors; from this light intensity is the major one. Photosynthesis and growth of plants are affected by heavy shade, which reduces light interception of leaves [1]. Planting high density reduces photosynthetic active radiation due to mutual shading or self-shading. The decrease in net assimilation rate (NAR), absolute growth rate (AGR), relative growth rate (RGR) and crop growth rate (CGR), while increasing planting density might be due to the decrease in light interception [2]. Coffee yield is decreased in agro-forestry systems, due to the limitation of photosynthesis due to low light availability. Plants undertake certain morphological modifications and physiological adaptations to increase photosynthetic rate like increase leaf area index [3]. Optimum leaf area index is very important; above the critical level may decline yield due to shading and competition for water, nutrients and light [4]. Leaves are exposed to light have more 
net photosynthesis than shaded leaves [5].

Planting high density is an important strategy to obtain higher coffee productivity. It is better vegetative growth performances on coffee cultivars under field conditions. High planting density is important for efficient use of nutrients and requires more nutrients than a single coffee tree per hole $[6$, 7]. The productivity of high population density of coffee is much greater than that of traditional plantings. At high population density production per unit area increases, but the yield per tree could be decreased. The reduction of yield per individual tree in close spacing might be the effect of shading of fruit bearing nods $[8,9]$.

Nursery management is the first step in coffee seedling production for field planting. However, nutrient availability during the nursery period is one of the factors that determine Coffee seedlings are more sensitive mainly to nitrogen and phosphorus, though potassium has also a significant effect. Previous study on the effect of compound NPK $(15: 15: 15)$ nutrients on coffee seedlings showed significant differences in leaf NPK content and nutrient uptake [10]. The seedlings growth is improved by additions of $2 \mathrm{~g} \mathrm{DAP} /$ seedling after the seedlings attain two pairs of true leaves [11]. This recommendation is for single seedling, but high population density needs more nutrient than a single seedling. High population density utilize resources efficiently, as plants grow the competition for resources becomes severe and leads to failure in production, because of this nutrient management is important for high planting density. The increasing of coffee seedling plant density per polythene tube would increase competition for light, water, and nutrients; this raised the question of whether high plant densities can enhance the physiological growth response of coffee seedlings or not? Therefore, the experiment was conducted with the objective: to evaluate the effect of planting density and fertilizer rate on some physiological parameters of Arabica coffee seedlings under nursery environments.

\section{Materials and Methods}

\subsection{Description of Experimental Area}

The study was carried out at the Jimma Agricultural Research Centre (JARC) in southwestern Ethiopia under the successful production of high-quality coffee seedlings.

nursery for eight months from (February 29 to October 29), 2018. Jimma is the National Coffee Research Coordinating Center of the Ethiopian Institute of Agricultural Research. It is one the potential of coffee growing areas in the country. It is located at $7^{\circ} 46^{\prime} \mathrm{N}$ latitude and $36^{\circ} 0^{\prime} \mathrm{E}$ longitude and at an altitude of 1753 meter above sea level. The site receives high amount of rainfall with a mean total of 1556.9 $\mathrm{mm}$ per annum. Its mean minimum and maximum temperature are $12.77^{\circ} \mathrm{C}$ and $26.14^{\circ} \mathrm{C}$, respectively [12].

\subsection{Experimental Design and Treatments}

The study was carried out using a factorial experiment arranged in completely randomized design with three replications. The treatments consisted of two released Arabica coffee cultivars that represent contrasting growth habits of compact (74110) and open (75227), four plant population densities (one, two, three and four plants per polythene tube) and three compound NPK rates (control, $5 \mathrm{~g}$ and $10 \mathrm{~g}$ ). Compound NPK fertilizer (22: 06: $12+$ Te) with 22\% total N, 6\% P2O5, 12\% $\mathrm{K} 2 \mathrm{O}$ and trace elements (Te) including $4 \% \mathrm{~S}, 0.15 \% \mathrm{~B}, 0.15 \%$ $\mathrm{Zn}$ and $0.002 \%$ Mo was used. Hence, twenty-four treatment combinations $(2 * 3 * 4)$ were used for the study.

\subsection{Experimental Procedures}

The growth medium was prepared from top soil $(0-30 \mathrm{~cm}$ depth) from Jimma (Melko) and sand at 3:1 ratio. A conventional black polythene tube with size of $(12 \mathrm{~cm}$ diameter and $22 \mathrm{~cm}$ length) was used and $2 \mathrm{~kg}$ of the soil medium mix was filled, arranged on seed beds and irrigated prior to seed sowing. For each treatment, six polythene tubes were used per plot and the prepared seed from selected of coffee genotypes were sown on each polythene tube following the designed planting density. At two pair of true leaves, the compound fertilizer rates were applied to each pot using ring basal method. All the routine pre-and post-sowing nursery operations including mulching, watering, shading and weed control were uniformly applied as recommended according to [13].

The relevant destructive data was collected twice (two and six pairs of true leaves) using the standard procedures. The following physiological data was collected:

Net Assimilation Rate (NAR): It was estimated as described by [14]

$$
\mathrm{NAR}=[(\text { PDWf }-\mathrm{PDWi}) /(\text { LAf - LAi })] *[(\operatorname{lnLAf}-\ln L A i) /(\mathrm{tf}-\mathrm{ti})],
$$

$N A R$ is the ratio of the difference between the final and initial dry weight (PDWf and PDWi) to final and initial leaf area ( $L A f$ and $L A i)$ and the ratio of natural logarithm initial to final leaf area ( $\ln L A f$ and $\ln L A i)$ to the period ( $t f-t i)$, expressed in $\mathrm{g} \mathrm{cm}-2 \mathrm{day}^{-1}$.

Absolute Growth Rate (AGR) in terms of weight: It was estimated as described by [15].

$$
\mathrm{AGR}=(\mathrm{PDWf}-\mathrm{PDWi}) /(\mathrm{tf}-\mathrm{ti}),
$$

where, PDWi and PDWf are whole plant dry weight at time $t 1$ and $t 2, t f$ and ti correspond to the final and initial time and expressed in $g$ day ${ }^{-1}$.

Relative Growth Rate (RGR): It was estimated as described by [16].

$$
\mathrm{RGR}=\mathrm{NAR} * \mathrm{SLA} * \mathrm{LWR},
$$

where, NAR, SLA and LWR are net assimilation rate, specific leaf area and leaf weight ratio, respectively, and expressed in $g$ $g^{-1} d a y^{-1}$.

Crop Growth Rate (CGR): It was estimated as described by [16]. 


\section{$\mathrm{CGR}=\mathrm{NAR} * \mathrm{LAI}$,}

where, LAI is leaf area index, respectively, and expressed in $g$ $\mathrm{cm}-2$ day $^{-1}$.

All relevant data was summarized and subjected to threeway analysis of variance (ANOVA) using SAS 9.3 version [17]. Treatments mean separation was done by least significant difference (LSD) at 5\% probability level.

\section{Results and Discussion}

The analysis of variance revealed that the three-way interaction effect of cultivar, population density and fertilizer rate was highly significant $(\mathrm{P} \leq 0.01)$ for absolute growth rate (AGR) and relative growth rate (RGR), whereas significant $(\mathrm{P} \leq 0.05)$ for net assimilation rate (NAR) and crop growth rate (CGR) (Table 1). The maximum values of 0.00041 , $0.014,0.036$ and 0.0011 were recorded from the combination of $74110 * \mathrm{PD} 1 * 5 \mathrm{~g}$ of NPK for NAR, AGR, RGR and CGR, respectively in compact coffee cultivar-74110. In open coffee cultivar (75227), the maximum values of $0.00052,0.024$, 0.049 and 0.0014 were recorded from combination of $75227 * \mathrm{PD} 1 * 5 \mathrm{~g}$ of NPK for NAR, AGR, RGR and CGR, respectively (Tables 2 and 3 ).

Table 1. Summary of the ANOVA for net assimilation rate (NAR), absolute growth rate $(A G R)$, relative growth rate $(R G R)$ and crop growth rate $(C G R)$.

\begin{tabular}{llllll}
\hline \multirow{2}{*}{ SV } & \multirow{2}{*}{ DF } & \multicolumn{4}{l}{ Mean Square } \\
\cline { 3 - 6 } & & NAR & AGR & RGR & CGR \\
\hline C & 1 & $2.3 .10^{-10 N S}$ & $1.4 .10^{-4 * *}$ & $2.9 .10^{-5 *}$ & $6.9 .10^{-8 * *}$ \\
PD & 3 & $3.3 .10^{-8 * *}$ & $3.6 .10^{-5 * *}$ & $1.5 .10^{-4 * *}$ & $1.0 .10^{-8 * *}$ \\
F & 2 & $1.8 .10^{-7 * *}$ & $1.10^{-3 * *}$ & $3.3 .10^{-3 * *}$ & $4.2 .10^{-7 * * *}$ \\
C*PD & 3 & $2.5 .10^{-9} \mathrm{NS}$ & $1.7 .10^{-5 * *}$ & $3.9 .10^{-5 * *}$ & $3.8 .10^{-8 * *}$ \\
C*F & 2 & $1.1 .10^{-9} \mathrm{NS}$ & $7.4 .10^{-6}$ & $2.4 .10^{-5 *}$ & $9.3 .10^{-9}$ \\
PD*F & 6 & $7.7 .10^{-9} * *$ & $8.1 .10^{-6 *}$ & $6.8 .10^{-5 * *}$ & $7.9 .10^{-8 * *}$ \\
C*PD*F & 6 & $2.8 .10^{-9} *$ & $1.9 .10^{-5 * *}$ & $1.9 .10^{-5 * *}$ & $2.62 .10^{-8 *}$ \\
Error & 46 & $1.02 .10^{-9}$ & $3.4 .10^{-6}$ & $5.2 .10^{-6}$ & $1.10^{-8}$ \\
CV $(\%)$ & & 11.94 & 19.76 & 10.59 & 17.65 \\
\hline
\end{tabular}

$\mathrm{SV}, \mathrm{DF}, \mathrm{C}, \mathrm{PD}, \mathrm{F}, * *^{* *}$ and NS represents source of variation, degree of freedom, cultivars, population densities, fertilizer rates, significant at $(\mathrm{P} \leq$ $0.05)$, highly significant at $(\mathrm{P} \leq 0.01)$ and non-significant, respectively.

\subsection{Net Assimilation Rate}

Net assimilation rate (NAR) was highly significantly ( $\mathrm{P} \leq$ $0.01)$ affected by population density and fertilizer rate, but no significant difference was observed between cultivars (Table 1). The results showed that, the maximum value $(0.00041 \mathrm{~g}$ $\left.\mathrm{cm}-2 \mathrm{day}^{-1}\right)$ and minimum value $\left(0.00014 \mathrm{~g} \mathrm{~cm}-2 \mathrm{day}^{-1}\right)$ were recorded from a combination of $74110 * \mathrm{PD} 1 * 5 \mathrm{~g}$ of NPK and $74110 *$ PD $4 * 10 \mathrm{~g}$ of NPK, respectively in compact cultivar74110. Similarly, the open coffee cultivar-75227 with PD1 and $5 \mathrm{~g}$ of NPK exhibited the highest response $\left(0.00052 \mathrm{~g} \mathrm{~cm}^{-}\right.$ ${ }^{1}$ day $\left.^{-1}\right)$, while $75227 * \mathrm{PD} 4 * 10 \mathrm{~g}$ of NPK had the lowest value $\left(0.00011 \mathrm{~g} \mathrm{~cm}^{2} \mathrm{day}^{-1}\right)$ for NAR (Table 2). The treatment combinations of $74110 * \mathrm{PD} 1 * 5 \mathrm{~g}$ of NPK and $75227 * \mathrm{PD} 1 * 5 \mathrm{~g}$ of NPK were $192.86 \%$ and $372.73 \%$ increments over the respective lowest values. In general, NAR decreased with increasing population density from PD1 to PD4 and fertilizer rate from $5 \mathrm{~g}$ to $10 \mathrm{~g}$ of NPK for both coffee cultivars. Population densityl (PD1) was $15.5 \%, 28 \%$ and $45.45 \%$ increment over population density2 (PD2), population density3 (PD3) and population density4 (PD4), respectively. Application of $5 \mathrm{~g}$ of NPK enhanced NAR at $29.63 \%$ and $94.4 \%$ than control and $10 \mathrm{~g}$ of NPK, respectively.

Maximum NAR with single seedling per polythene tube (PD1) and application of 5g of NPK could be probably be associated with increased efficiency utilization of solar radiation, which enhanced photosynthetic capacity of seedlings of both coffee cultivars. The photosynthetic rate of a given plant is affected by light intensity. Competition for the common resources increases shading between leaves and lead to insufficient carbon fixation [18]. Population density may increase mutual or self-shading of the plants and, thus, reduce light interception and NAR of individual leaves, even in the presence of the adequate amount of water and nutrients as competition for light limits growth of coffee under high plantation as a result of lower photosynthetic rate in shaded leaves. Similarly, [19] have reported that when all leaves are exposed to full sun light the NAR is increased, but it is decreased when leaves are fully or partially shaded. It has also been reported that increased plant density may cause self-shading of plants and, hence, decline in NAR [20].

Plant photosynthesis, hence, NAR is known to be greatly affected by radiation, temperature and nutrient availability [21], with regard to this, it is believed that leaf area index (LAI) is indirectly affected NAR, as excessive leaf area causes mutual shading of photo synthetically active leave, thus LAI has negative effect on NAR. On the other hand, higher specific leaf area (SLA) of shaded coffee seedlings may result in lower photosynthetic rates and a decrease in NAR. Heavy shading due to reduced light penetration by the upper canopy can result in increased competition for light for photosynthesis, which leads to undesirable growth. Excess shade affects net photosynthesis due to insufficient light interception [22]. Coffee cultivated at high planting density may have some limitations in energy absorption capacity and such characteristic are more pronounced in plants with higher total leaf area, reduce the amount of energy that reaches the lower leaves in the canopy. In line with this result, increasing population density increase mutual shading finally decreases NAR [23].

\subsection{Absolute Growth Rate}

Absolute growth rate (AGR) was highly significantly $(\mathrm{P} \leq$ 0.01 ) affected by cultivar, population density and fertilizer treatments (Table 1). The results showed that treatment combination of $74110 * \mathrm{PD} 2 * 5 \mathrm{~g}$ of NPK had the highest $\left(0.019 \mathrm{~g} \mathrm{day}^{-1}\right)$ AGR while the lowest value $\left(0.00169 \mathrm{~g}\right.$ day $\left.^{-1}\right)$ was recorded for $74110 * \mathrm{PD} 4 * 10 \mathrm{~g}$ of NPK in cultivar-74110. Similarly, cultivar-75227 with PD1 and 5g of NPK exhibited the highest $\left(0.024 \mathrm{~g}\right.$ day $\left.^{-1}\right)$ while $75227 * \mathrm{PD} 4 * 10 \mathrm{~g}$ of NPK had the lowest value $\left(0.0033 \mathrm{~g} \mathrm{day}^{-1}\right)$ for AGR (Table 2). Combinations of $74110 * \mathrm{PD} 2 * 5 \mathrm{~g}$ of NPK and $75227 * \mathrm{PD} 1 * 5 \mathrm{~g}$ of NPK had $375 \%$ and $627.27 \%$ increments on AGR over the lowest values in cultivar-74110 and 75227, 
respectively.

AGR is expresses variation in plant growth weight for a given time, and increase plant density had negative effects on AGR; it might be due to low light interception [24]. Population density1 (PD1) was 10\%, 20.87\% and 48.65\% increments on AGR over population density2 (PD2), population density3 (PD3) and population density3 (PD4), respectively. Application of $5 \mathrm{~g}$ of NPK enhanced AGR than control and $10 \mathrm{~g}$ of NPK with increments of $110 \%$ and $321.1 \%$, respectively. Application of $10 \mathrm{~g}$ of NPK decreased AGR when compared with other treatments; it might be related to toxicity problems and a similar toxicity problem was observed with other parameters. This result in line with [25] reported that due to the high dosage of NPK fertilizer, the dry matter yield of coffee seedlings was decreased.

Table 2. Interaction effect of coffee cultivar, population density and fertilizer rate on net assimilation rate (NAR) and absolute growth rate (AGR) of coffee seedling.

\begin{tabular}{|c|c|c|c|c|c|c|c|c|}
\hline \multirow{2}{*}{ NPK (g) } & \multicolumn{4}{|c|}{ Cultivar -74110 (Compact) } & \multicolumn{4}{|c|}{ Cultivar -75227 (Open) } \\
\hline & PD1 & PD2 & PD3 & PD4 & PD1 & PD2 & PD3 & PD4 \\
\hline \multicolumn{9}{|c|}{ Net Assimilation Rate $\left(\mathrm{g} \mathrm{cm}^{-2}\right.$ day $\left.^{-1}\right)$} \\
\hline 0 & $0.000299^{\mathrm{d}}$ & $0.000286^{\mathrm{de}}$ & $0.000283^{\mathrm{de}}$ & $0.00022^{\text {gh }}$ & $0.000283^{\text {de }}$ & $0.00028^{\mathrm{de}}$ & $0.00027^{\mathrm{d}-\mathrm{f}}$ & $0.00025^{\mathrm{e}-\mathrm{g}}$ \\
\hline 5 & $0.00041^{\mathrm{b}}$ & $0.00036^{\mathrm{bc}}$ & $0.00032^{\text {cd }}$ & $0.0003^{\mathrm{d}}$ & $0.00052^{\mathrm{a}}$ & $0.00031^{\mathrm{d}}$ & $0.0003^{\mathrm{d}}$ & $0.0003^{\mathrm{d}}$ \\
\hline 10 & $0.00021^{\mathrm{gh}}$ & $0.00022^{\mathrm{fg}}$ & $0.00017^{\mathrm{hi}}$ & $0.00014^{\mathrm{ij}}$ & $0.0002^{\text {gh }}$ & $0.00021^{\mathrm{gh}}$ & $0.00015^{\mathrm{ij}}$ & $0.00011^{\mathrm{j}}$ \\
\hline $\operatorname{LSD}(5 \%)$ & & & & & & & & $5.2 .10^{-7}$ \\
\hline CV $(\%)$ & & & & & & & & 11.94 \\
\hline 0 & $0.008^{\mathrm{h}-\mathrm{k}}$ & $0.006^{\mathrm{j}-\mathrm{m}}$ & $0.0067^{\mathrm{i}-\mathrm{I}}$ & $0.005^{1-\mathrm{n}}$ & $0.011^{\mathrm{fg}}$ & $0.0086^{\mathrm{h}-\mathrm{j}}$ & $0.009^{\mathrm{hi}}$ & $0.006^{\mathrm{j}-\mathrm{m}}$ \\
\hline 5 & $0.014^{\text {def }}$ & $0.019^{\mathrm{b}}$ & $0.012^{\mathrm{fg}}$ & $0.0126^{\mathrm{e}-\mathrm{g}}$ & $0.024^{\mathrm{a}}$ & $0.015^{\mathrm{de}}$ & $0.0186^{\mathrm{bc}}$ & $0.016^{\mathrm{cd}}$ \\
\hline 10 & $0.003^{\text {no }}$ & $0.004^{1-o}$ & $0.0017^{\circ}$ & $0.00169^{\circ}$ & $0.004^{1-0}$ & $0.0067^{\mathrm{i}-1}$ & $0.0056^{\mathrm{k}-\mathrm{n}}$ & $0.0033^{\mathrm{m}-\mathrm{o}}$ \\
\hline $\operatorname{LSD}(5 \%)$ & & & & & & & & 0.003 \\
\hline CV $(\%)$ & & & & & & & & 19.76 \\
\hline
\end{tabular}

Figures followed with same letters within a column and row for a given variable are not significantly different at 5\% probability level. PD1, PD2, PD3 and PD4 are represents population density1, 2, 3 and 4, respectively.

\subsection{Relative Growth Rate}

The result indicated that relative growth rate (RGR) was highly significantly $(\mathrm{P} \leq 0.01)$ affected by fertilizer rate and population density. The difference between coffee cultivars was also significant $(P \leq 0.05)$ for RGR (Table 1). The highest $\left(0.036 \mathrm{~g} \mathrm{~g}^{-1}\right.$ day $\left.^{-1}\right)$ RGR of cultivar -74110 was recorded for $74110 * \mathrm{PD} 1 * 5 \mathrm{~g}$ of $\mathrm{NPK}$, whereas the lowest $\left(0.008 \mathrm{~g} \mathrm{~g}^{-1} \mathrm{day}^{-1}\right)$ was for $74110 *$ PD $4 * 10 \mathrm{~g}$ of NPK. The maximum value of $0.049 \mathrm{~g} \mathrm{~g}^{-1} \mathrm{day}^{-1}$ of RGR for cultivar 75227 was recorded for $75227 * \mathrm{PD} 1 * 5 \mathrm{~g}$ of NPK, whereas the minimum $\left(0.0087 \mathrm{~g} \mathrm{~g}^{-1} \mathrm{day}^{-1}\right)$ was recorded for $75227 *$ PD $4 * 10 \mathrm{~g}$ of NPK (Table 3 ).

Single seedling per polythene tube (PD1) and $5 \mathrm{~g}$ NPK resulted in higher RGR in both coffee cultivars than the other treatment combinations, but cultivar -75227 had higher than cultivar-74110. Application of $5 \mathrm{~g}$ of NPK exhibited $80 \%$ and $271.1 \%$ a higher value of RGR as compared to the control and $10 \mathrm{~g}$ of NPK, respectively, in cultivar-74110. The increment was $122.73 \%$ and $444.4 \%$ higher than the control and $10 \mathrm{~g}$ of NPK, respectively, for the open coffee cultivar75227. Lower RGR was recorded for higher planting density in both cultivars. This could probably be attributed to low light interception due to mutual shading of coffee seedlings and, thus, low rate of dry matter production and poor growing conditions, such as water and nutrient stresses as well as self-shading. Similar findings have been reported by [26], indicating that plant species may differ considerably in RGR, as a result of variations in competition for both a biotic (temperature, water, light and nutrients) and biotic factors. The result of the current study was also in agreement with the findings of [27] who reported that self-shading by dense canopies reduces RGR. Similarly, it has been reported that wheat plants exhibited high RGR at the initial stage, but the RGR decreased later on with increased shading [28]. It has also been reported that increases in planting density had negative effects on RGR and NAR as the result of low light interception [24].

\subsection{Crop Growth Rate}

The result indicated that crop growth rate (CGR) was highly significantly $(\mathrm{P} \leq 0.01)$ affected by coffee cultivar, population density and fertilizer rate (Table 1). It was observed that CGR was more enhanced with combinations of $74110^{*} \mathrm{PD} 1 * 5 \mathrm{~g}$ of NPK $\left(0.0011 \mathrm{~g} \mathrm{~cm}-2 \mathrm{day}^{-1}\right)$ and $75227 * \mathrm{PD} 1 * 5 \mathrm{~g}$ of NPK $\left(0.0014 \mathrm{~g} \mathrm{~cm}-2 \mathrm{day}^{-1}\right)$, whereas lowest values $\left(0.00009\right.$ and $0.0001 \mathrm{~g} \mathrm{~cm}^{-2}$ day $\left.^{-1}\right)$ were recorded for $74110 * \mathrm{PD} 1 * 10 \mathrm{~g}$ of NPK and $75227 * \mathrm{PD} 1 * 10 \mathrm{~g}$ of NPK in cultivar -74110 and 75227 , respectively (Table 3 ).

The highest CGR was obtained from the treatment combination of PD1 and 5g of NPK for both coffee cultivars, but cultivar-75227 had higher values than cultivar-74110. The decrease in CGR with increasing population density from PD1 to PD4 it might be related with self-shading and low light interception, which might have led to the low rate of photosynthesis and dry matter accumulation and, thus, lower CGR. This result was in line with [2] who reported that increase planting density had a negative effect on CGR in maize. Application of $5 \mathrm{~g}$ of NPK exhibited more CGR than did the other fertilizer treatments. The decline in CGR of the control plot and with the application of $10 \mathrm{~g}$ of NPK could be associated with the decline of LAI. It has been reported that 
maximum CGR occurs when plants are large enough to exploit all the environmental factors to the greatest degree. The result of the present study was in agreement with the findings of [21] who reported that increases in plant population density significantly reduced NAR and CGR due to low light interception. CGR is directly related to the amount of radiation intercepted by the crop. Similarly, it has been reported that CGR is directly affected by plant photosynthetic area, as an increase in plant population density increases leaf area and finally affects CGR [29, 30].

Table 3. Effect of coffee cultivar, population density and fertilizer rate on relative growth rate (RGR) and crop growth rate (CGR) of coffee seedling.

\begin{tabular}{|c|c|c|c|c|c|c|c|c|}
\hline \multirow{2}{*}{ NPK (g) } & \multicolumn{4}{|c|}{ Cultivar -74110 (Compact) } & \multicolumn{4}{|c|}{ Cultivar -75227 (Open) } \\
\hline \multirow{2}{*}{\multicolumn{9}{|c|}{ Relative Growth Rate $\left(\mathrm{g} \mathrm{g}^{-1}\right.$ day $\left.^{-1}\right)$}} \\
\hline & & & & & & & & \\
\hline 0 & $0.02^{e-g}$ & $0.0223^{\mathrm{e}}$ & $0.018^{\mathrm{e}-\mathrm{h}}$ & $0.015^{\mathrm{h}-\mathrm{j}}$ & $0.022^{\mathrm{e}}$ & $0.0197^{\mathrm{eg}}$ & $0.021^{\mathrm{ef}}$ & $0.0167^{-\mathrm{ei}}$ \\
\hline 5 & $0.036^{\mathrm{b}}$ & $0.034^{\mathrm{b}}$ & $0.0323^{\mathrm{bc}}$ & $0.028^{\mathrm{d}}$ & $0.049^{\mathrm{a}}$ & $0.032^{\mathrm{bc}}$ & $0.033^{\mathrm{bc}}$ & $0.0293^{\mathrm{cd}}$ \\
\hline 10 & $0.0097^{\mathrm{kl}}$ & $0.016^{\text {ghi }}$ & $0.011^{\mathrm{jkl}}$ & $0.008^{1}$ & $0.009^{1}$ & $0.014^{\mathrm{ijk}}$ & $0.0113^{j-1}$ & $0.0087^{1}$ \\
\hline $\operatorname{LSD}(5 \%)$ & & & & & & & & 0.004 \\
\hline CV $(\%)$ & & & & & & & & 10.59 \\
\hline \multicolumn{9}{|c|}{ Crop Growth Rate $\left(\mathrm{g} \mathrm{cm}^{-2} \mathrm{day}^{-1}\right)$} \\
\hline 0 & $0.00045^{\mathrm{e}-\mathrm{h}}$ & $0.00049^{\text {ef }}$ & $0.00032^{\mathrm{f}-\mathrm{j}}$ & $0.000226^{\mathrm{i}-\mathrm{m}}$ & $0.00053^{\mathrm{e}}$ & $0.00037^{\mathrm{e}-\mathrm{i}}$ & $0.00046^{\mathrm{e}-\mathrm{g}}$ & $0.00027^{\mathrm{h}-1}$ \\
\hline 5 & $0.0011^{\mathrm{b}}$ & $0.001^{\mathrm{b}}$ & $0.00092^{\mathrm{b}-\mathrm{d}}$ & $0.00076^{\mathrm{d}}$ & $0.0014^{\mathrm{a}}$ & $0.00083^{\text {cd }}$ & $0.000996^{\mathrm{bc}}$ & $0.00099^{\mathrm{bc}}$ \\
\hline 10 & $0.00009^{\mathrm{m}}$ & $0.00025^{\mathrm{i}-\mathrm{m}}$ & $0.00023^{\mathrm{i}-\mathrm{m}}$ & $0.00013^{\mathrm{k}-\mathrm{m}}$ & $0.0001^{\mathrm{lm}}$ & $0.00034^{\mathrm{f}-\mathrm{i}}$ & $0.00029^{\mathrm{g}-\mathrm{k}}$ & $0.00015^{\mathrm{j}-\mathrm{m}}$ \\
\hline $\operatorname{LSD}(5 \%)$ & & & & & & & & 0.0002 \\
\hline CV $(\%)$ & & & & & & & & 17.65 \\
\hline
\end{tabular}

Figures followed with same letters within a column and row for a given variable are not significantly different at 5\% probability level. PD1, PD2, PD3 and PD4 are represents population density 1, 2, 3 and 4, respectively.

\section{Conclusion}

Coffee production depends on several factors, among which quality of coffee seedlings to greatly affect the rate of establishment and subsequent growth and yield performance of genotypes. Poor preparation of growing media and improper planting density in polythene tube is considered as the major factors affecting growth and physiology of seedlings during the nursery period. It was observed that planting one seed per polythene tube or population density 1 (PD1) and fertilized with $5 \mathrm{~g}$ of NPK gave the highest NAR, AGR, RGR and CGR in both cultivars, but open coffee cultivar-75227 had higher than the compact cultivar-74110 in all parameters. In general, a single seedling per polythene tube (PD1) is best population density when compared with other population density and application $5 \mathrm{~g}$ of NPK enhanced physiological parameters (NAR, AGR, RGR and CGR) than other treatments in both cultivars.

\section{Recommendation}

In high planting density, self-shading is one the major problems that decreases light interception of individual leaves. Therefore, more attention should be given to cova planting system under field conditions and intensive pruning practices should be done to increase light interception on each part of leaves.

\section{Acknowledgements}

We would like to thanks the Ethiopian Institute of Agricultural Research (EIAR) for financial support, and Jimma Agricultural Research Center (JARC), Coffee Agronomy and Physiology research division staff members largely Mr. Alemseged Yilma and Mohammed Aman for their unlimited technical support during designing, implementing the treatments and data recording time.

\section{References}

[1] Morais, H., Marur, C. J., Caramori, P. H., Ribeiro, M. A. and Gomes, J. C., 2003. Physiological characteristics and growth of coffee plants grown under shade of pigeonpea and unshaded. Pesquisa Agropecuária Brasileira, 38 (10): 11311137.

[2] Amanullah, Asif, M., Nawab, K., Shah, Z., Hassan, M., Khan, A. Z., Khalil, S. K., Hussain, Z., Tariq, M. and Rahman, H. 2010. Impact of planting density and P-fertilizer source on the growth analysis of maize. Pakistan Journal of Botany, 42 (4): 2349-2357.

[3] Lee, D. W., 1985. Duplicating foliage shade for research on plant development. Horticultural Science (USA). Limitation to photosynthesis in coffee leaves from different canopy positions. Plant Physiology and Biochemistry, 46: 884-890.

[4] Taye Kufa and Burkhardt J. 2015. Physiological growth response in seedlings of Arabica coffee genotypes under contrasting nursery microenvironments. Plant, 3 (5): 47-56.

[5] Araujo, W. L., Dias, P. C., Moraes, G. A. B. K., Celin, E. F., Cunha, R. L. and Barros, R. S. 2008. Limitation to photosynthesis in coffee leaves from different canopy positions. Plant Physiology and Biochemistry, 46: 884-890.

[6] Taye Kufa. 1996. Cova planting favors coffee production at Melko. Institute of Agricultural Research Newsletter, Agricultural Research, 12: 5-6.

[7] Paulo, E. M. and Furlani, E. Jr. 2010. Yield performance and leaf nutrient of coffee cultivars under different plant density. Science of Agriculture, 67 (6): 720-726. 
[8] DaMatta, F. 2004. Eco-physiological constraints on the production of shaded and unshaded coffee: a review. Field Crops Research, 86: 99-114.

[9] Avelino, J., Barboza, B., Araya, J., Fonseca, C. and Davrieux, F. 2005. Effect of slope exposure, altitude and yield on coffee quality in two altitude terroirs of Costa Rica, and Santa Maria de Dota. Journal Science Food Agriculture, 85: $1869-1876$

[10] Ibiremo, O. S. and Akanbi, O. S. O. 2016. Soil properties and nutrient uptake of coffee seedlings as influenced by NPK fertilizer formulations in Ibadan, Southwest Nigeria. British Journal of Applied Science \& Technology, 12 (3): 1-8.

[11] Taye Kufa, Mesfin Abebe and Paulos Dubale. 1999. Effect of nitrogen, phosphorus and organic fertilizer on growth and development of coffee seedlings. In: Proceedings of African Crop Science Conference. Volume 4, Kampala, Uganda. pp. 213-223.

[12] Fuad Abafita, 2010. Studies on the diversity of insect pests in wild and cultivated coffee plantations in and around Jimma, Southwest Ethiopia. pp. 20-21.

[13] Tesfaye Shimber, Alemseged Yilma, Taye Kufa, Endale Taye and Anteneh Netsere. 2005. "Coffee seedlings management and production." Amharic version, Ethiopian Agricultural Research Organization, Addis Ababa, Ethiopia. 17pp.

[14] Antonio Jackson de Jesus Souza, Rubens José Guimarães, Alberto Colombo, José Antonio do Vale Sant'Ana and Dalyse Toledo Castanheira. 2016. Quantitative analysis of growth in coffee plants cultivated with a water-retaining polymer in an irrigated system, Revista Ciência Agronômica, 47 (1): 162-171.

[15] Radford, P. J. 1967. Growth analysis formula, their uses and abuses. Crop Science, 7: 171-175.

[16] John, P. A. L., Asia Khamzina and Martin Worbes. 2006. The analyses of physiological and morphological attributes of 10 tree species for early determination of their suitability to afforest degraded landscapes in the Aral Sea Basin of Uzbekistan, Forest Ecology and Management, 221 (1-3): 249-259.

[17] SAS (Statistical Analysis System). 2011. SAS/STAT 9.3 user's guide. Cray, NC: SAS Institute Inc.

[18] Naser Al-Suhaibani, Salah El-Hendawy and Urs Schmidhalter. 2013. Influence of Varied Plant Density on Growth, Yield and Economic Return of Drip Irrigated Fababean (Vicia faba L.). Turkish Journal of Field Crops, 18 (2): 185-197.

[19] Arvind Kumar and Purohit, S. S. 2014. Plant Physiology: Fundamentals and Application. Second Enlarged Edition. India. $353 \mathrm{p}$.
[20] Poorter, H. 1989. Inter specific variation in relative growth rate: on ecological causes and physiological consequences. In: Lambers H. (Ed.), Causes and Consequences of Variation in Growth Rate and Productivity in Higher Plants. SPB Academic Publishing, The Hague, the Netherlands, pp: 45-68.

[21] Behnam Ahmadi, Amir Hosein, Shirani Rad and Ali khorgami. 2014. The effect of plant population densities and cultivars on forage yield, qualitative traits and growth indices in canola forage (Brassica napus L.). European Journal of Zoological Research, 3 (1): 62-70.

[22] DaMatta, F. M., 2018. Coffee tree growth and environmental acclimation. In Achieving sustainable cultivation of coffee. Burleigh Dodds Science Publishing, pp: 39-66.

[23] Konard, M., Kosegarten, H., Appel, T. and Kirkby, E. A. 2001. Principles of Plant Nutrition. Fifth Edition. 299 p.

[24] Amanullah, Rahman, H., Shah, Z. and Shah, P. 2008. Plant density and nitrogen effects on growth dynamics and light interception of maize. Archives of Agronomy and Soil Science, 54: 401-411.

[25] Ibiremo, O. S., Akanbi, O. S. O., Oloyede, A. A., Adebowale, L. A. and Adeyemi, E. A. 2013. Evaluation of NPK fertilizer formulations on the growth and dry matter yield of coffee seedlings. Nigerian Journal of Soil Science, 23 (1): 22-26.

[26] Hendrik Poorter. 2016. Inter specific variation in relative growth rate: on ecological causes and physiological consequences. Cause and consequences of variation in growth rate and productivity of higher plants. Department of Plant Ecology, University of Utrecht, Lange Nieuwstraat 106, 3512 PN Utrecht, The Netherlands, 24: 45-68.

[27] Poorter, H. 2002. Plant Growth and Carbon Economy. Encyclopaedia of Life Sciences, pp. 1-6.

[28] Pandey, M. and Singh, T. 2015. Effect of intercropping systems and different levels of nutrients on dry matter accumulation and physiological growth parameters of bed planted wheat (Triricum aestivum L.). Indian Journal Science, 8 (11): 1-6.

[29] Jeffrey, T. E., Larry, C. P. and Earl, D. V. 2005. Light interception and yield potential of short season maize (Zea mays L.) hybrids in the mid south. Agronomy Journal, 97 (1): 225-234.

[30] Habibzadeh, Y., Mamghani, R., Kashani, A. and Mesgharbashi, M. 2006. Effect of density on yield and some vegetative and reproductive characters of three mungbean genotypes in Ahwaz area. Iranian Journal of Agricultural Science, 37: 227335 . 